\title{
PENGGUNAAN METODE JIGSAW UNTUK MENINGKATKAN PRESTASI BELAJAR SISWA PADA MATERI MEDAN MAGNET KELAS IX SMPN 10 MALANG
}

\author{
RADIT PURWIKORO \\ SMP Negeri 10 Malang \\ Email : radite2015agust@gmail.com
}

\begin{abstract}
ABSTRAK
Tujuan penelitian ini adalah untuk mengetahui dampak dan implementasi metode jigsaw dalam belajar mata pelajaran IPA ( Fisika ) dapat meningkatkan prestasi belajar siswa kelas IX SMP Negeri 10 Malang Kota Malang. Metode yang digunakan dalam penelitian ini adalah metode penelitian tindakan kelas (PTK). Sedangkan teknik pengumpulan data yang digunakan adalah observasi, wawancara, dokumentasi dan analisis data secara deskriptif. Penelitian ini dilakukan dalam 3 siklus yakni siklus I siklus II dan siklus III. Subjek penelitian adalah 34 orang siswa kelas IX SMP Negeri 10 Malang Tahun Pelajaran 2016/2017. Setelah dilakukan penelitian di kelas IX SMP Negeri 10 Malang, hasil belajar siswa dengan menggunakan metode pembelajaran Model jigsaw, dapat meningkatkan prestasi belajar Siswa Kelas IX SMP Negeri 10 Malang. Sebagai buktinya bahwa, dari 34 siswa yang melakukan kegiatan belajar didapatkan pada perolehan nilai 80,90 dan 100 mengalami peningkatan. Yang memperoleh nilai 80/cukup baik, pada siklus I : $8(23,53 \%)$ siswa pada siklus II : $9(26,47 \%)$ siswa pada siklus III : 13 $(38,24 \%)$ siswa. Yang memperoleh nilai 90/baik pada siklus I : $1(2,94 \%)$ siswa pada siklus II : $5(14,71 \%)$ siswa pada siklus III : $10(29,41 \%)$ siswa. Yang memperoleh nilai 100/sangat baik pada siklus I : $0(0 \%)$ siswa pada siklus II : $0(0 \%)$ siswa pada siklus III : $1(2,94 \%)$ siswa. Dengan demikian, metode pembelajaran dengan metode jigsaw dapat meningkatkan hasil belajar siswa kelas IX semester genap tahun pelajaran 2016/2017.
\end{abstract}

Kata Kunci : Peningkatan Prestasi, IPA ( Fisika ), Metode Jigsaw

\section{ABSTRACT}

The purpose of this study was to determine the impact and implementation of the jigsaw method in learning science (Physics) subjects to improve student achievement in class IX of SMP Negeri 10 Malang, Malang City. The method used in this research is classroom action research (CAR). While the data collection techniques used were observation, interviews, documentation and descriptive data analysis. This research was conducted in 3 cycles, namely cycle I, cycle II and cycle III. The research subjects were 34 grade IX students of SMP Negeri 10 Malang in the 2016/2017 academic year. After doing research in class IX SMP Negeri 10 Malang, student learning outcomes using the jigsaw model learning method, can improve student achievement in class IX SMP Negeri 10 Malang. As proof that, from 34 students who carried out learning activities, it was found that the scores of 80, 90 and 100 had increased. Those who scored 80/good enough, in the first cycle: 8 (23.53\%) students in the second cycle: $9(26.47 \%)$ students in the third cycle: 13 (38.24\%) students. Those who scored 90/good in the first cycle: 1 (2.94\%) students in the second cycle: $5(14.71 \%)$ students in the third cycle: $10(29.41 \%)$ students. Those who scored 100/excellent in the first cycle: $0(0 \%)$ students in the second cycle: $0(0 \%)$ students in the third cycle: $1(2,94 \%)$ students. Thus, the jigsaw method of learning can improve the learning outcomes of class IX students in the even semester of 2016/2017 academic year.

Keywords: Improved Achievement, Science (Physics), Jigsaw . Method

\section{PENDAHULUAN}

Hasil belajar yang mengkhusus pada prestasi belajar sangat dipengaruhi oleh strategi dan perencanaan yang dilakukan oleh guru sebagai pelaksana pendidikan terdepan. Strategi dan perencanaan yang dimaksud adalah suatu kegiatan yang menunjuk kepada bagaimana guru mengatur keseluruhan proses belajar mengajar, meliputi : mengatur waktu, pemenggalan 
penyajian, pemilihan metode, pemilihan pendekatan, dan sebagainya. Artinya bagaimana guru memikirkan strategi, sekaligus memikirkan metode dan pendekatannya juga dalam upaya mencapai hasil belajar yang sesuai dengan program yang direncanakan. Untuk itu, dalam upaya meningkatkan prestasi belajar siswa, guru perlu memperkenalkan model pembelajaran yang dapat menjadikan suasana belajar siswa yang menyenangkan dan lebih efektif (Isjoni 2007), dengan harapan kondisi kegiatan belajar siswa akan lebih enjoy (menikmati) sesuai dengan keinginan belajar siswa.

Menurut Hamalik (2001) guru dituntut untuk memiliki kemampuan mendesain programnya dan sekaligus menentukan strategi instruksional yang harus ditempuh. Para guru harus memiliki ketrampilan memilih dan menggunakan metode mengajar untuk diterapkan dalam sistem pembelajaran yang efektif, oleh karena itu, guru dipandang sebagai agen modernisasi dalam segala bidang. Usaha utama yang dapat dilakukan oleh guru adalah melalui program pendidikan bagi para siswa. Dalam melakukan usaha pencapaian tujuan pendidikan di sekolah tersebut, guru berperan penting dalam menggunakan model pembelajaran dan cara untuk mencapai hasil belajar yang optimal.

Berdasarkan pernyataan tersebut, peneliti akan melakukan suatu kegiatan penelitian tindakan kelas (action research) berkaitan dengan penggunaan model pembelajaran dalam upaya meningkatkan prestasi belajar siswa kelas IX Siswa SMP Negeri 10 Malang Kota Malang dalam kegiatan belajar mengajar mata pelajaran IPA ( Fisika ). Penelitian tindakan tersebut dimaksudkan untuk mengetahui sejauh mana dampak model pembelajaran yang diterapkan dalam belajar mata pelajaran IPA ( Fisika ) terhadap prestasi belajar siswa kelas IX SMP Negeri 10 Malang Kota Malang. Model pembelajaran yang dimaksud dalam penelitian ini adalah model pembelajaran dengan teknik jigsaw. Mengapa harus model jigsaw?

Seperti telah dijabarkan di atas bahwa siswa akan lebih memperoleh prestasi belajar yang baik bila dalam kegiatan belajar melibatkan semua siswa melakukan aktivitas sesuai dengan materi pembelajaran yang dipelajari. Sejauh ini pendidikan di Indonesia masih didominasi oleh pandangan bahwa pengetahuan sebagai perangkat fakta-fakta yang harus dihafal. Kelas masih berfokus pada guru sebagai sumber utama pengetahuan, kemudian ceramah menjadikan pilihan utama strategi belajar. Untuk itu diperlukan sebuah strategi baru yang lebih memberdayakan siswa. Sebuah strategi belajar yang tidak mengharuskan siswa menghafal fakta-fakta, tetapi sebuah strategi yang mendorong siswa mengkonstruksikan pengetahuan dibenak mereka sendiri.

Lebih spesifik alasan pemilihan metode jigsaw dalam upaya menigkatkan prestasi belajar siswa, karena teknik Jigsaw adalah suatu model belajar kelompok yang digambarkan sebagai berikut : (a) Satu kelas dibagi dalam kelompok-kelompok kecil, banyaknya anggota kelompok disesuaikan dengan banyaknya masalah/problem yang ditawarkan guru. Kelompok-kelompok ini disebut dengan home group, (b) Setiap anggota home group diberi problem yang berbedabeda, tapi masing-masing home group di beri persoalan yang sama. Dengan batasan waktu tertentu masing-masing anggota menyelesaikan problem secara individu, (c) Anggota home group akan berpencar dan membentuk kelompok baru yang membawa persoalan sama. Kelompok ini disebut expert group (kelompok ahli). Di kelompok inilah mereka berdiskusi untuk menyamakan persepsi atas jawaban mereka, dan (d) Setelah selesai mereka kembali ke home group dan anggotaanggota akan mensosialisasikan hasil/jawaban dari kelompok ahli.

Kenyataan yang ada di lapangan pendidikan proses pencapaian tujuan pembelajaran di SMP Negeri 10 Malang Kota Malang, masih menggunakan paradigma lama dengan memperlakukan guru sebagai sumber utama dalam belajar walaupun sekarang kurikulum telah menggunakan Kurikulum K-13. Sehingga tidak menutup kemungkinan hasil belajar yang dicapai oleh siswapun terkesan monoton, karena hanya menghafal suatu fakta dan guru dipandang sebagai sumber utama dalam belajar. Salah satu hasil belajar yang diperoleh adalah mata pelajaran IPA. Belajar IPA (Fisika) lebih mengutamakan pada kemampuan berpikir logika, tidak menghafalkan suatu fakta. Namun kenyataan ini masih terlihat dalam pencapaian hasil belajar di Kelas IX SMP Negeri 10 Malang Kota Malang. 
Melalui kegiatan pembelajaran dengan metode jigsaw ini diharapkan hasil belajar IPA(Fisika) materi medan magnet di sekitar arus listrik pada siswa kelas IX SMP Negeri 10 Malang Kota Malang akan diperoleh sesuai dengan tujuan yang diharapkan.

\section{METODE PENELITIAN}

Pendekatan dan jenis penelitian yang dilakukan oleh peneliti adalah menggunakan metode penelitian tindakan kelas, berdasarkan pendapat Waseso (1994) bahwa penelitian tindakan merupakan proses daur ulang, mulai tahap perencanaan, pelaksanaan tindakan dan pemantauan, refleksi yang mungkin diikuti dengan perencanaan ulang. Penelitian bertujuan mengembangkan ketrampilan-ketrampilan baru atau cara pendekatan baru untuk memecahkan masalah dengan penerapan langsung di dunia faktual (Zuriah, 2003). Menurut Carr dan Kemmis (1986), mengatakan bahwa penelitian tindakan adalah suatu bentuk penelaahan inquiry melalui refleksi diri yang dilakukan oleh peserta kegiatan pendidikan tertentu dalam situasi sosial, untuk memperbaiki rasionalitas dan kebenaran serta keabsahan. Penelitian Tindakan Kelas ini dilakukan di SMP Negeri 10 Malang dengan subjek penelitian yakni siswa kelas IX berjumlah 34 siswa.

Penelitian ini dilakukan dengan siklus terdiri dari siklus I, siklus II dan siklus III. Tahap tahap dalam setiap penelitian tindakan yaitu : (1)Refleksi, (2)Perencanaan, (3)Tindakan Observasi dan (4)Refleksi Akhir. Dalam tahap ini diharapkan (a) dapat menerjemahkan gambaran yang jelas tentang metode jigsawdalam proses belajar mengajar, dan alasan pemilihan tema tersebut, (b) draft kerja tindakan tiap individu dan kelompok, (c) gambaran tentang pihak yang terlibat, (d) garis besar rencana program kerja (time schedulle), (e) memonitor perubahan saat penelitian berlangsung, dan (f) gambaran awal tentang efisiensi data yang terkumpul. Tahap ini memastikan bahwa siswa kelas IX SMP Negeri 10 Malang Kota Malang dijadikan sebagai obyek penelitian dengan pertimbangan karakteristik yang dimiliki kelas ini sesuai dengan permasalahan yang akan dibahas oleh peneliti.

Pengumpulan data penelitian tindakan ini diantaranya melalui : observasi, wawancara, dokumentasi dan analisis data. Teknik analisis data yang digunakan dalam penelitian ini adalah analisis deskriptif Moleong (2000). Dengan maksud bahwa penelitian deskriptif dirancang untuk memperoleh informasi tentang status gejala pada saat penelitian dilakukan. Menerapkan tiga alur kegiatan dalam analisis deskriptif yang menjadi satu kesatuan yang tak dapat terpisahkan, yaitu: (1) Reduksi data, (2) Penyajian data, dan (3) Penarikan kesimpulun atau verifikasi.

\section{HASIL DAN PEMBAHASAN}

Dari hasil Penelitian ditemukan bahwa penerapan model pendekatan jigsaw dalam kegiatan belajar mengajar, dapat meningkatkan prestasi belajar siswa kelas IX SMP Negeri 10 Malang Kota Malang. Hal ini sesuai dengan data perhitungan analisa siklus 1, 2 dan 3 dengan peningkatan nilai dari siklus 1 ke siklus ke 2: 20\%, dan dari siklus 2 ke siklus 3: 20\% setelah diterapkannya model pendekatan jigsaw dalam kegiatan belajar mengajar di kelas IX SMP Negeri 10 Malang Kota Malang. Hal ini bisa dilihat pada Tabel dan Grafik di bawah ini.

Tabel.1 Perolehan Nilai Siswa dalam 3 siklus

\begin{tabular}{lcccccc}
\hline Nilai & 50 & 60 & 70 & 80 & 90 & 100 \\
\hline Siklus 1 & 6 & 9 & 10 & 8 & 1 & 0 \\
Siklus 2 & 2 & 6 & 12 & 9 & 5 & 0 \\
Siklus 3 & 0 & 1 & 9 & 13 & 10 & 1
\end{tabular}




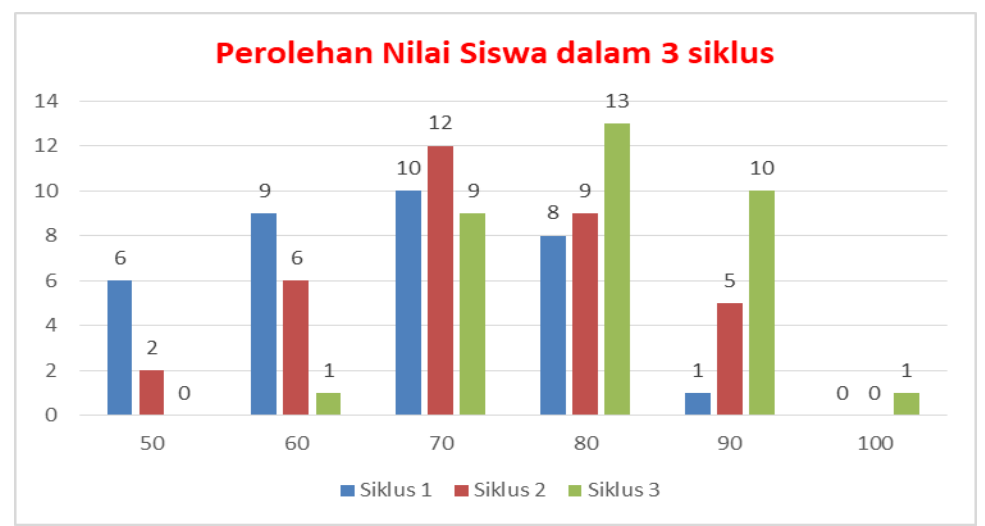

Tabel. 1 Perolehan Nilai Siswa dalam 3 siklus

Berdasarkan hasil perolehan nilai evaluasi selama siklus 1, 2 dan 3 memperoleh temuan bahwa jumlah siswa yang memperoleh nilai 50, 60 dan 70 mengalami penurunan, sedangkan jumlah siswa yang nilainya 80, 90 dan 100 mengalami kenaikan. Hal ini berarti bahwa penerapan model pendekatan jigsaw dalam kegiatan belajar mampu meningkatkan penguasaan konsep siswa pada konsep arus listrik disekitar medan magnet. Pembelajaran dengan model pendekatan jigsaw dalam penelitian ini mendorong siswa aktif dan saling membantu dalam menguasai materi pelajaran untuk mencapai hasil belajar yang diharapkan. Hal ini mendukung temuan penelitian bahwa model pendekatan jigsaw dapat meningkatkan hasil belajar siswa (Ramlawati, 2007)

Tabel. 2 Rekapitulasi Nilai dalam 3 siklus

\begin{tabular}{cccc}
\hline Nilai & Siklus 1 & Siklus 2 & Siklus 3 \\
\hline MAX & 90 & 90 & 100 \\
MIN & 50 & 50 & 60 \\
RATA-RATA & 66,8 & 72,6 & 80,3 \\
\% KETUNTASAN & $56 \%$ & $76 \%$ & $97 \%$
\end{tabular}

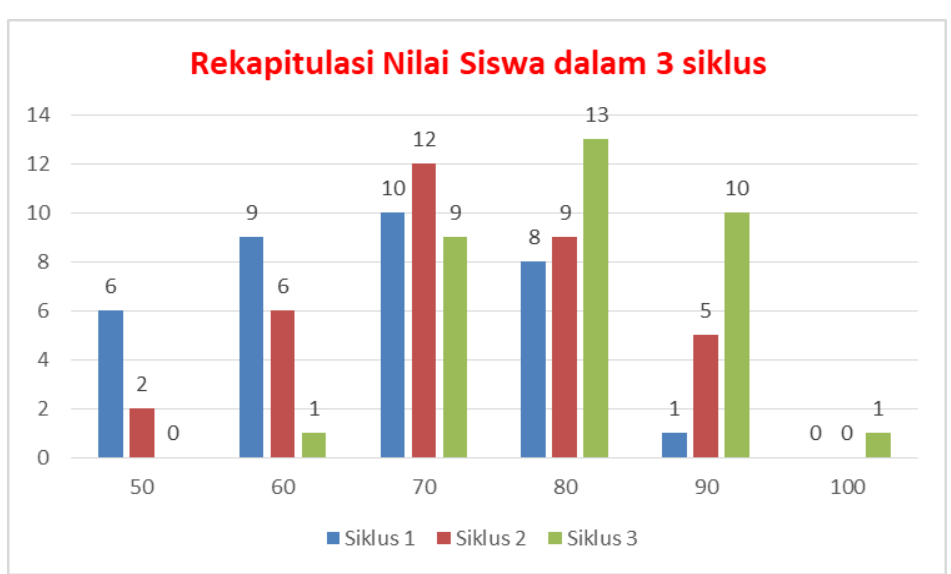

Tabel. 2 Rekapitulasi Nilai dalam 3 siklus

Berdasarkan rekapitulasi nilai pada siklus 1,2 dan 3 memperlihatkan bahwa untuk nilai tertinggi (MAX) pada siklus 1: 90 pada siklus ke 3 menjadi 100, sedangkan untuk nilai terendah (MIN) pada siklus 1: 50 pada siklus 3 menjadi 60, selanjutnya untuk rata-rata nilai pada siklus 1: 66,8 pada siklus 3 menjadi 80,3, serta pada bagian prosentase ketuntasan pada siklus 1: $56 \%$ maka pada siklus ke 3 meningkat menjadi 97\%. Dengan mengimplementasikan model pendekatan jigsaw dalam pembelajaran, kegiatan belajar mengajar sangat efektif sehingga dapat mempengaruhi hasil belajar yang diperoleh oleh siswa sebagai pembelajar Sulastri, Y., \& Rochintaniawati, D. (2009). Dengan demikian dapat dipastikan bahwa selama kegiatan 
pembelajaran dengan model jigsaw, pencapaian hasil belajar siswa lebih baik dibandingkan dengan strategi yang tradisional. Artinya kegiatan pembelajaran di sekolah selama ini masih didasari paradigma lama bahwa pengetahuan merupakan perangkat fakta-fakta yang harus dihafal.

Hal ini diperkuat oleh hasil penelitian Ramlawati (2007) bahwa model pembelajaran kooperatif dapat digunakan untuk meningkatkan hasil belajar siswa. Demikian juga menurut Wartono, dkk, (2004) pembelajaran kooperatif merupakan suatu model pengajaran dimana siswa belajar dalam kelompok-kelompok kecil yang memiliki tingkat kemampuan berbeda. Dalam menyelesaikan tugas kelompok, setiap anggota saling bekerja sama dan membantu untuk memahami suatu bahan pembelajaran. Sedangkan menurut Kunandar (2008), pembelajaran kooperatif adalah pembelajaran yang secara sadar dan sengaja mengembangkan interaksi yang saling asuh antar siswa untuk menghindari ketersinggungan dan kesalahpahaman yang dapat menimbulkan permusuhan. Menurut Lie (2002), pembelajaran kooperatif dapat mencapai hasil yang maksimal apabila menerapkan lima unsur pembelajaran kooperatif, yaitu saling ketergantungan positif, tanggung jawab perseorangan, tatap muka, komunikasi antar anggota dan evaluasi proses kelompok.

\section{KESIMPULAN}

Berdasarkan hasil perolehan nilai evaluasi selama siklus 1, 2 dan 3 memperoleh temuan bahwa jumlah siswa yang memperoleh nilai 50, 60 dan 70 mengalami penurunan, sedangkan jumlah siswa yang nilainya 80, 90 dan 100 mengalami kenaikan, demikian juga dari rekapitulasi nilai memperlihatkan bahwa untuk nilai tertinggi (MAX) pada siklus 1: 90 pada siklus ke 3 menjadi 100, sedangkan untuk nilai terendah (MIN) pada siklus 1: 50 pada siklus 3 menjadi 60, selanjutnya untuk rata-rata nilai pada siklus 1: 66,8 pada siklus 3 menjadi 80,3 , serta pada bagian prosentase ketuntasan pada siklus 1: 56\% maka pada siklus ke 3 meningkat menjadi 97\%.Hal ini berarti bahwa penerapan model pendekatan jigsaw dalam kegiatan belajar mampu meningkatkan penguasaan konsep siswa pada konsep arus listrik disekitar medan, yang selanjutnya dapat mempengaruhi untuk meningkatkan prestasi hasil belajar yang diperoleh oleh siswa di SMP Negeri 10 Malang kota Malang.

\section{DAFTAR PUSTAKA}

Hamalik, O. 2001. Prose. Belajar Mengajar. Jakarta:PT Bum] Aksara

Isjoni. 2007. Cooperative Learning Efektifitas Pembelajaran Kelompok. Bandung Alfabeta.

Kunandar. 2007. Langkah Mudah Penelitian Tindakan Kelas sebagai Pengembangan Profesi Guru. Jakarta: PT Raja Grafindo Persada.

Lie. 2002. Cooperative Learning. Jakarta: Gramedia Widiasarana Indonesia.

Moleong, L. J. 2000. Metodologi Penelitian Kualitatif. Bandung: PT. Remaja Rosdakarya.

Ramlawati. 2007. Penerapan Pendekatan Kontekstual dengan Setting Kooperatif untuk Meningkatkan Hasil Belajar Kimia Siswa Kelas XI IPA 3 SMA 3 Takalar. Makalah Seminar Internasional Pendidikan IPA.Jakarta: UIN Syarif Hidayatulloh.

Sulastri, Y., \& Rochintaniawati, D. (2009). Pengaruh Penggunaan Pembelajaran Kooperatif Tipe Jigsaw Dalam Pembelajaran Biologi Di SMPN 2 Cimalaka. Jurnal pengajaran MIPA, 13(1), 15-22.

Wartono, dkk. 2004. Materi Pelatihan Terintegrasi Sains. Jakarta: Departemen Pendidikan Nasional.

Zuriah, N. 2003. Penelitian Tindakan dalam Bidang Pendidikan Fisika. Edisi Pertama. Malang: Bayu Media Publishing 